\title{
A new species of Marumomysis (Mysidacea: Mysidae: Erythropini) from the benthos of the Bellingshausen Sea (Southern Ocean)
}

\author{
CARLOS SAN VICENTE
}

Carrer Nou, 8, 43839 Creixell, Tarragona, Spain.

\begin{abstract}
SUMMARY: A new mysid species, Marumomysis antarctica n. sp., is described from specimens sampled with a suprabenthic sled in the Bellingshausen Sea (Southern Ocean). The new mysid is characterised by the small eyes lacking visual elements and with a long horn projecting anteriodorsally, the trilobate labrum and the shape and armature of the endopod of the uropod and telson. This new species is the first Marumomysis species described from the benthos (1320-1895 m depth) of the Southern Ocean.
\end{abstract}

Keywords: taxonomy, Crustacea, Peracarida, Mysidae, Bellingshausen Sea, Antarctica.

RESUMEN: UNA NUEVA ESPECIE DE MARUMomysis (MysidACEA: MYSIDAE: ERYTHROPINI) DEL BENTOS PROFUNDO DEL MAR DE BellingShausen (OCÉANO Austral). - Una nueva especie de misidáceo, Marumomysis antarctica $\mathrm{n}$. sp., se describe en base a los ejemplares muestreados con un trineo suprabentónico en el mar de Bellingshausen (Océano Austral). La nueva especie de misidáceo se caracteriza por poseer unos ojos pequeños, sin elementos visuales y provistos de un cuerno que se proyecta anterodorsalmente, un labro trilobado y la forma y armadura del endopodio del urópodo y del telson. Esta nueva especie es la primera del género Marumomysis descrita en el bentos profundo (1320-1895 m) del Océano Austral.

Palabras clave: taxonomía, Crustacea, Peracarida, Mysidae, mar de Bellingshausen, Antártida.

\section{INTRODUCTION}

Fifty-nine species of mysids are reported from the Southern Ocean; in the Antarctic region 37 species are known, of which $51 \%$ (19 species) are endemic (Brandt et al., 1988). Among the Mysidacea, the tribe Erythropini (family Mysidae, sub-family Mysinae) is extremely diverse, displaying many peculiar and uncommon morphological features that are considered to be adaptations to the deep-sea habitat (e.g. reductions and specialisations of the compound eyes). This high diversity has made generic and specific classification complicated within the Erythropini.
The genus Marumomysis Murano, 1999 was established for the reception of 1 adult female and 1 probable adult male from about 2000 metre depth in the Sulu Sea (southeastern Asian seas). The genus resembles Mysimenzies, established by Bacescu (1971), but is easily distinguished from the latter by many characters: the antennular peduncle, the labrum and the exopod of the first thoracic leg (Murano and Machline, 1999; Murano, 1999). Up to now, only one species is known in the genus: $M$. hakuhoae (Murano, 1999).

During the BENTART-06 oceanographic cruise to the Bellingshausen Sea (austral summer 2006), Marumomysis specimens were sampled with a 
suprabenthic sled and with a plankton net installed in the mouth of a 2-m Agassiz trawl. A detailed morphological study of these specimens revealed that they actually belonged to a species new to science. This paper deals with the description of this new species and presents a revision of the diagnosis of the genus.

\section{MATERIAL AND METHODS}

Marumomysis antarctica n. sp. was collected with a suprabenthic sled equipped with 3 superimposed nets $(0.5 \mathrm{~mm}$ mesh size $)$ that sample the motile fauna in the $10-50 \mathrm{~cm}(\mathrm{~A}), 55-95 \mathrm{~cm}$ (B) and 100$140 \mathrm{~cm}(\mathrm{C})$ near-bottom water layers. Every layer has an opening of $80 \mathrm{~cm}$ width and $41 \mathrm{~cm}$ height. The sled is equipped with an opening closing-system

TABLE 1. - Geographical location and depth of the BENTART-06 sampling stations and stations at which the mysid Marumomysis antarctica $\mathrm{n}$. sp., was collected (+).

\begin{tabular}{|c|c|c|c|c|}
\hline Station & Date & $\begin{array}{l}\text { Latitude } \\
\text { (S) }\end{array}$ & $\begin{array}{l}\text { Longitude } \\
\text { (W) }\end{array}$ & $\begin{array}{l}\text { Depth Presence } \\
\text { (m) }\end{array}$ \\
\hline
\end{tabular}

Suprabenthic sled

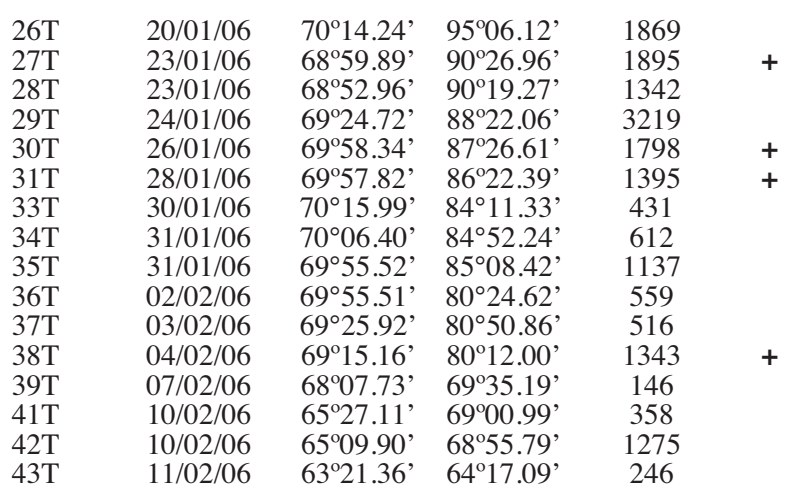

Plankton net installed in mouth of 2-m Agassiz trawl

\begin{tabular}{|c|c|c|c|c|c|}
\hline 26MPK & $22 / 01 / 06$ & $70^{\circ} 14.52^{\prime}$ & $95^{\circ} 01.98^{\prime}$ & 1958 & \\
\hline 27MPK & $22 / 01 / 06$ & $68^{\circ} 59.52^{\prime}$ & $90^{\circ} 23.86^{\prime}$ & 1838 & + \\
\hline $28 \mathrm{MPK}$ & $23 / 01 / 06$ & $68^{\circ} 52.31^{\prime}$ & $90^{\circ} 18.08^{\prime}$ & 1191 & \\
\hline 29MPK & $24 / 01 / 06$ & $69^{\circ} 24.19^{\prime}$ & $88^{\circ} 20.19^{\prime}$ & 3310 & \\
\hline 30MPK & $26 / 01 / 06$ & $69^{\circ} 58.84^{\prime}$ & $87^{\circ} 29.04^{\prime}$ & 1801 & \\
\hline 31MPK & $27 / 01 / 06$ & $69^{\circ} 57.88^{\prime}$ & $86^{\circ} 24.04^{\prime}$ & 1407 & \\
\hline $32 \mathrm{MPK}$ & $28 / 01 / 06$ & $69^{\circ} 48.24^{\prime}$ & $86^{\circ} 31.83^{\prime}$ & 1848 & + \\
\hline 33MPK & $30 / 01 / 06$ & $70^{\circ} 17.35$ & $84^{\circ} 17.04^{\prime}$ & 430 & \\
\hline $34 \mathrm{MPK}$ & $30 / 01 / 06$ & $70^{\circ} 07.35^{\prime}$ & $84^{\circ} 52.09^{\prime}$ & 603 & \\
\hline $35 \mathrm{MPK}$ & $31 / 01 / 06$ & $69^{\circ} 55.68^{\prime}$ & $85^{\circ} 09.66^{\prime}$ & 1132 & \\
\hline $36 \mathrm{MPK}$ & $02 / 02 / 06$ & $69^{\circ} 55.79^{\prime}$ & $80^{\circ} 24.39^{\prime}$ & 559 & \\
\hline 37MPK & $03 / 02 / 06$ & $69^{\circ} 25.93^{\prime}$ & $80^{\circ} 24.83^{\prime}$ & 508 & \\
\hline $38 \mathrm{MPK}$ & $04 / 02 / 06$ & $69^{\circ} 14.27^{\prime}$ & $80^{\circ} 01.64^{\prime}$ & 1320 & + \\
\hline 39MPK & $07 / 02 / 06$ & $68^{\circ} 07.72^{\prime}$ & $69^{\circ} 35.31^{\prime}$ & 167 & \\
\hline 40MPK & $08 / 02 / 06$ & $66^{\circ} 57.55^{\prime}$ & $72^{\circ} 34.97^{\prime}$ & 402 & \\
\hline 41MPK & $09 / 02 / 06$ & $65^{\circ} 28.29^{\prime}$ & $69^{\circ} 01.71^{\prime}$ & 350 & \\
\hline $42 \mathrm{MPK}$ & $10 / 02 / 06$ & $65^{\circ} 09.99^{\prime}$ & $68^{\circ} 56.18^{\prime}$ & 1272 & \\
\hline 43MPK & $11 / 02 / 06$ & $63^{\circ} 21.71^{\prime}$ & $64^{\circ} 17.68^{\prime}$ & 254 & \\
\hline
\end{tabular}

activated by contact with the sea-floor (preventing contamination by pelagic organisms from the water column) (San Vicente et al. 1997; San Vicente et al. 2006). The sledge was hauled over the ground for 2$4 \mathrm{~min}$ at a mean velocity of 1.5-2 knots. Some specimens were also obtained with a plankton net installed in mouth of a 2-m Agassiz trawl. During the austral summer 2006 benthic assemblages were investigated at 17 and 18 stations (suprabenthic sled and Agassiz trawl, respectively) located around Bellingshausen Sea and the Southwest Antarctic Peninsula, at depths ranging from 146 to $3219 \mathrm{~m}$. The dates, positions and depths of the BENTART-06 sampling stations and the 7 stations at which this mysid was collected are shown in Table 1 .

Samples were preserved in a solution of $10 \%$ formaldehyde in seawater and taken to the laboratory for demographic analysis. After the sorting of the other swimming species, the individuals of the new species were counted, ascribed to one of the 6 population categories defined by Mauchline (1980) (juveniles; immature, brooding and empty females; immature and mature males), and measured under a dissecting microscope with an eyepiece micrometer. The individual size was determined from the measurement of the carapace length (CL: measured from the apex of the rostrum to the posterior dorsal edge of the carapace, in lateral view) to the nearest 0.05 $\mathrm{mm}$; the total length (TL: from the apex of the rostrum to the posterior end of the telson, excluding spines) was also measured in some undamaged specimens.

\section{TAXONOMY}

\author{
Order MysidaceA Boas 1883 \\ Suborder MYsidA Haworth, 1825 \\ Family MYsIDAE Dana, 1850 \\ Genus Marumomysis Murano, 1999
}

Diagnosis. Carapace produced anteriorly into evenly rounded rostral place. Eyes small, fused along median line, without visual elements. Antennular peduncle with first joint provided with triangular ventral carina. Antennal scale large, without terminal lobe; outer margin naked, terminating in strong triangular process. Mandible with large molar portion. First thoracic leg provided with a flagelliform exopod; endite from basis developed, armed on inner margin with setae. Endopod of uro- 
pod armed on inner margin of statocyst region with 1 spine. Telson truncate; lateral margin dentate; apical margin with 3-4 pairs of long spines and 1 median short spine, lateral denticles and apical median spine without articulation at base.

\section{Marumomysis antarctica $\mathrm{n}$. sp.}

(Figs. 1-4)

Material examined. Holotype (ICMM17/2007) deposited at the Institut de Ciències del Mar (ICM), Barcelona, Spain. Mature male, $19.6 \mathrm{~mm}$ TL. Sampling data: 23 January 2006. Sample reference: 27TA (10-50 cm water layer above bottom). Type locality: Bellingshausen Sea, 6859'53'S 90²6'58'W, 1895 m depth. Paratype material (ICMM18/2007) deposited at the Institut de Ciències del Mar (ICM), Barcelona, Spain. Sample reference: 27TA (10-50 cm water layer above bottom), Bellingshausen Sea, 68 59'53"'S - 90'26'58”W, $1895 \mathrm{~m}$ depth: 1 mature male and 1 mature female $23.6 \mathrm{~mm}$ TL.

Other material. Station 27TA (10-50 cm water layer above bottom), 60 juveniles, 3 immature males, 45 mature males, 11 immature females, 31 empty females. Station 27TC (100-140 cm water layer above bottom), 1 immature female. Station 27MPK (plankton net installed in mouth of 2-m Agassiz trawl: PNAT), 2 empty females. Station 30TA (10-50 cm water layer above bottom), 1 juvenile, 2 immature females, 2 empty females. Station 30 TB $(55-95 \mathrm{~cm}$ water layer above bottom), 1 immature female, 2 empty females. Station 30 TC (100-140 cm water layer above bottom), 1 empty female. Station 30MPK (PNAT), 1 empty female. Station 31TA $(10-50 \mathrm{~cm}$ water layer above bottom), 1 mature male, 1 immature female, 4 empty females. Station 31TB (55-95 cm water layer above bottom), 1 immature female. Station 32MPK (PNAT), 1 immature female. Station 38TA (10-50 cm water layer above bottom), 1 immature male, 2 mature males, 4 immature females, 5 empty females. Station $38 \mathrm{~TB}(55-95 \mathrm{~cm}$ water layer above bottom), 1 immature female, 1 empty female. Station 38MPK (PNAT), 2 mature males. (Table 2).

Diagnosis. Labrum trilobate, without anterior spine. Telson truncate, three times as long as broad at base; lateral margins almost parallel, provided with 23-25 denticles along whole length, apical margin with 4 pairs of long spines and 1 median short spine; lateral denticles and apical median spine without articulation at base.

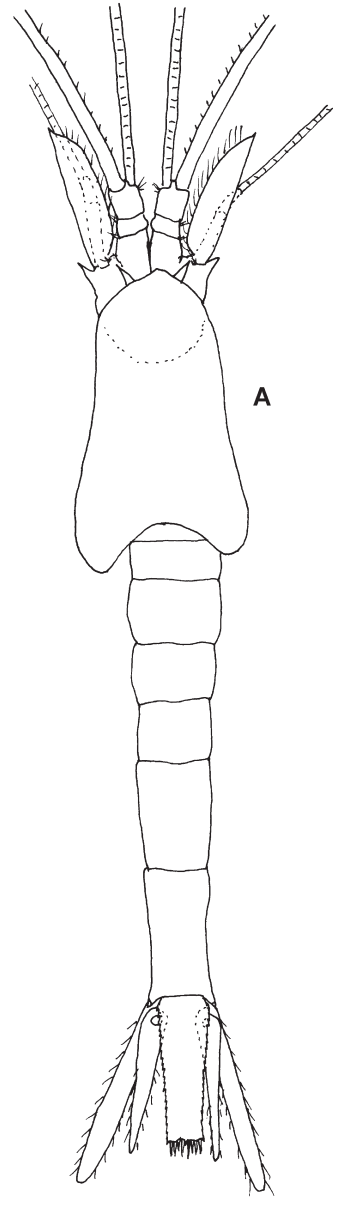

A $2 \mathrm{~mm}$

B $1 \mathrm{~mm}$

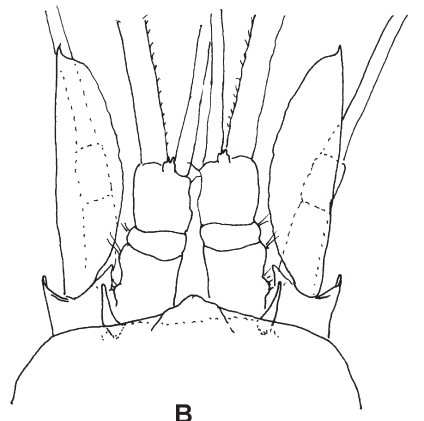

B

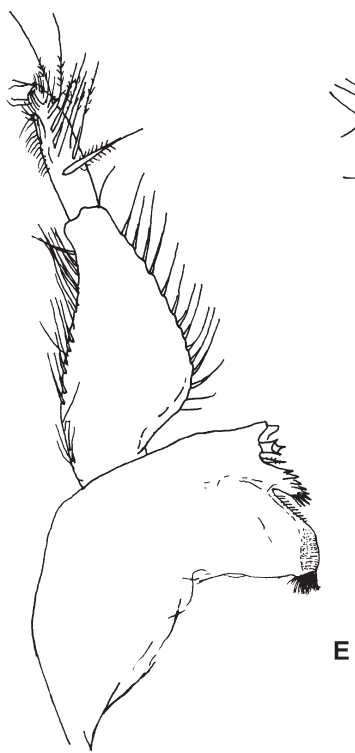

C D

E F G

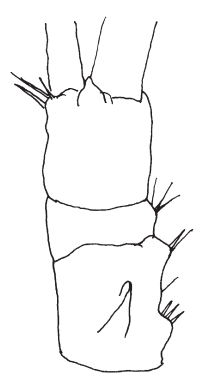

C
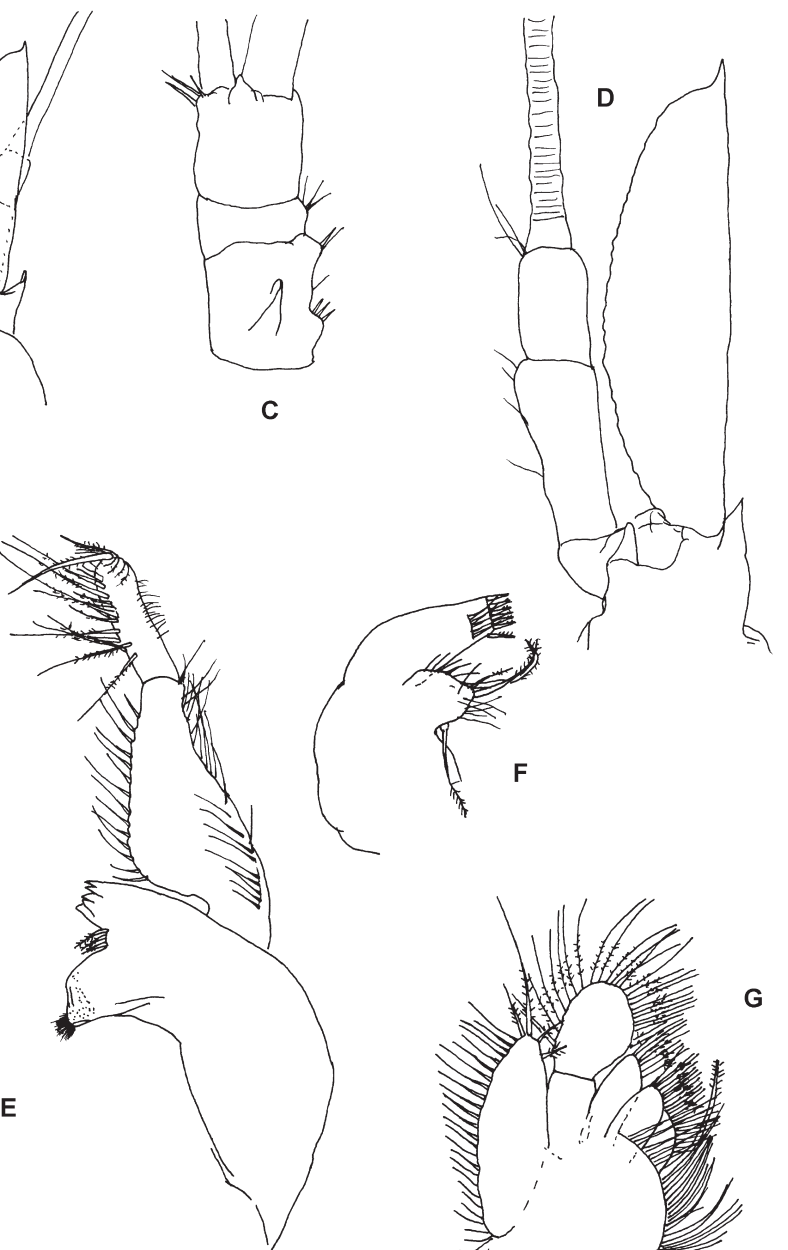

F

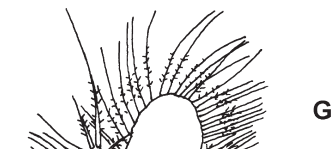

G

FIG. 1. - Marumomysis antarctica n. sp., holotype, mature male: A, dorsal view; B, anterior end of body in dorsal view; C, antennule in ventral view; D, antenna in dorsal view; E, mandibles; F, maxillule; G, maxilla. 


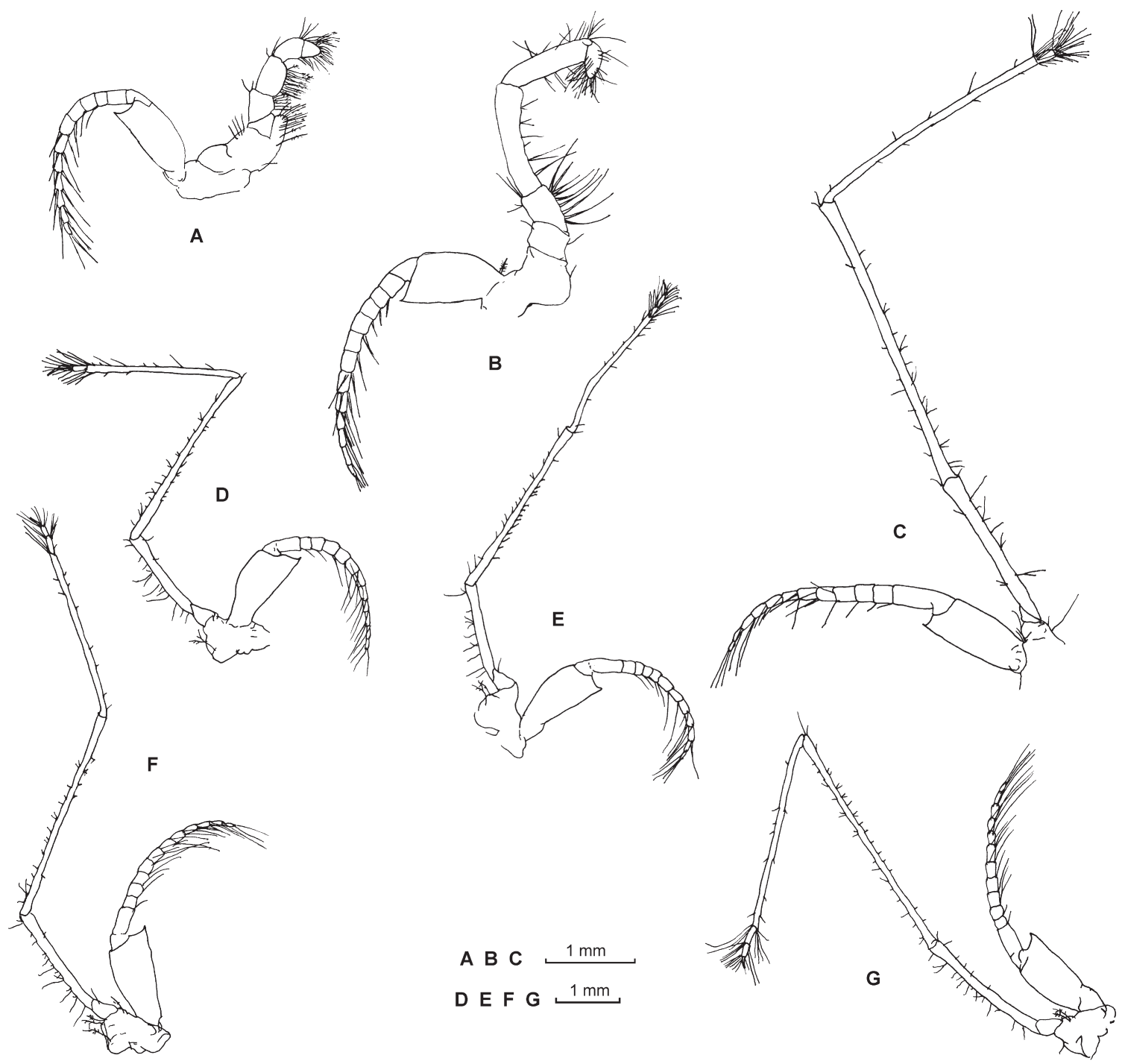

FIG. 2. - Marumomysis antarctica n. sp., holotype, mature male: A,1st thoracopod; B, 2nd thoracopod; C, 7th thoracopod. Paratype, mature male: D, 3rd thoracopod; E, 4th thoracopod; F, 5th thoracopod; G, 6th thoracopod.

Description. The morphological characteristics refer to both sexes, unless otherwise stated.

Carapace produced anteriorly into broadly rounded rostrum extending to base of antennular peduncle; anterolateral corner rounded; posterior margin emarginated dorsally, leaving last thoracic somite uncovered; posterolateral lobe covering anterior half abdominal somite (Figs. 1A, 4A).

Eyes small, fused along median line, without visual elements, covered by carapace extending past basal half; each half with anterior margin straight, with acute horn projecting anteriodorsally reaching the first half of the basal joint of the antennular peduncle (Figs. 1B, 4C).

Antennular peduncle small; article 1 longer than broad, with pronounced triangular ventral carina, proximal end of outer margin with small swelling armed with 3 short setae, outer distal corner slightly produced and armed with several setae; article 2 short, half as long as broad, armed with 3 setae near distal end of outer margin; 3rd article slightly longer than broad, armed with 3 setae near distal end of inner margin, blunt process armed with setae at the distal dorsal end; article 3 of male with processus masculinus very small, without setae (Figs. 1C, 4B).

Sympod of antenna relatively slender, with outer distal angle produced into a long acute process; inner distal corner with 1 bluntly pointed process. Peduncle slender, slightly overreaching distal end of antennular peduncle; article 1 short, as long as broad; 2nd article longest, 3 times as long as broad; article 3 twice as long as broad. Antennal scale four times as long as maximum width, extending for nearly half of its length beyond the antennular 
peduncle; outer margin straight, smooth, terminating in strong triangular process (Fig. 1D).

Mandibles with large molar portion, inner posterior margin with a brush of fine setae; well-developed lacinia mobilis and spine row; palp slender, 2nd article expanded, with setae on both margins, about twice as long as 3rd; third article armed on distal $2 / 3$ of inner margin with about 10 setae arranged pectinately (Fig. 1E). Maxillule with three long plumose setae on inner margin of inner lobe, outer lobe with 7 spines on distal margin and 5 setae on ventral surface (Fig. 1F). Maxilla with distal article of endopod oval, a little longer than wide, densely setose on inner margin and scarcely setose on outer margin; exopod relatively slender, extending beyond distal margin of proximal article of endopod, with 23 setae on outer margin and 4 plumose setae on distal margin (Fig.1G). Labrum with 3 anterior lobes, without anterior spine (Fig. 4D).

Endopod of first thoracopod small, with short preischium and dactylus, ischium, merus and carpopropodus similar in length; endite of basis developed, armed on lateral margin with about 10 plumose setae; dactylus hirsute; carpopropodus with 3 distal setae on outer and inner distal margins, respectively; merus bearing 12 plumose spines on inner margin; ischium with 8 plumose spines on inner margin preischium without setae and basis with 4 setae on inner margin; exopod 12-segmented, basal plate with outer distal corner pointed (Fig. 2A).

Endopod of 2nd thoracopod relatively slender, ischium with 9 long setae on inner margin; preischium short with one seta on inner margin; merus longest with few setae; carpopropodus with long and short

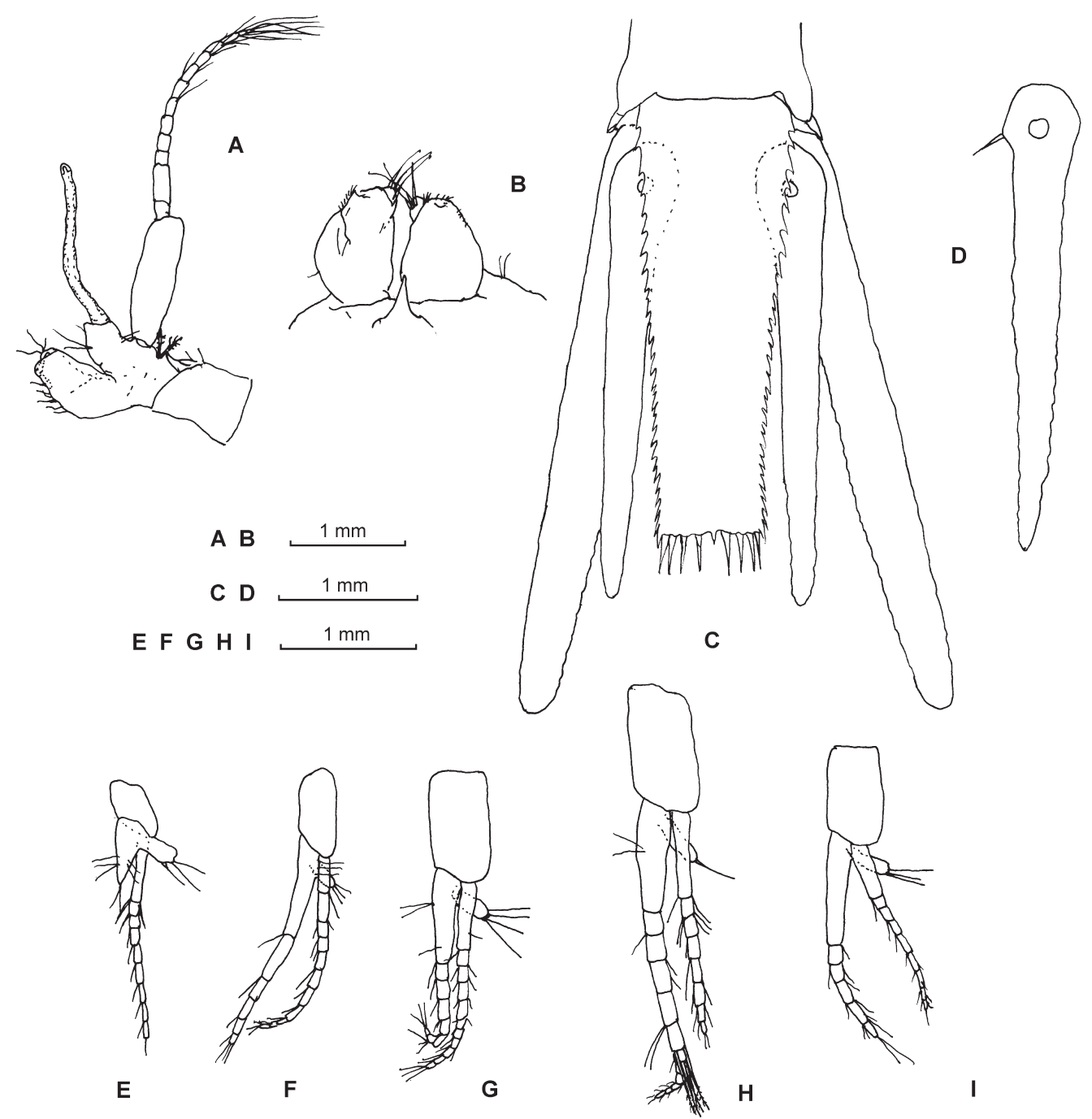

FIG. 3. - Marumomysis antarctica n. sp., holotype, mature male: A, 8th thoracopod; B, sternum of 8th somite and penis in ventral view; C, uropods and telson; D, endopod of uropod in ventral view; E, 1st pleopod; F, 2nd pleopod; G, 3rd pleopod; H, 4th pleopod; I, 5th pleopod. 


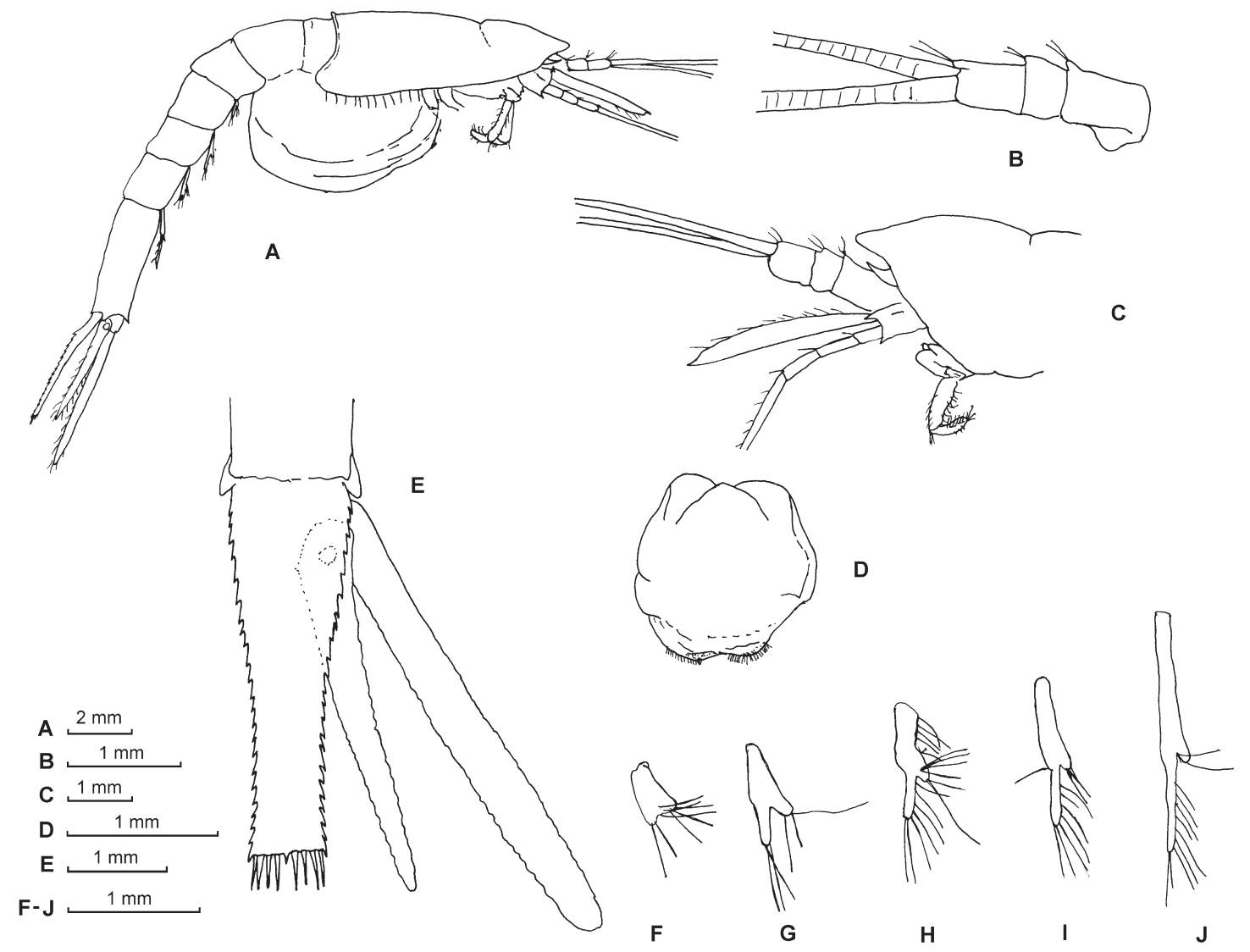

FIG. 4. - Marumomysis antarctica $\mathrm{n}$. sp., paratype, empty female: A, whole body in lateral view; B, antennule in lateral view; C, anterior end of body in lateral view; D, labrum; E, telson and right uropod; F, 1st pleopod; G, 2nd pleopod; H, 3rd pleopod; I, 4th pleopod; J, 5th pleopod.

setae on distal $2 / 3$ of its length; dactylus more than twice as long as broad, hirsute; exopod 13-segmented, basal plate with outer distal corner pointed (Fig. 2B).

3 rd to 7 th thoracic endopods very long and fragile; carpus nearly four times as long as the propodus from which is divided by an oblique suture; propodus divided into two hirsute subsegments, except 7th thoracic endopod (only one subsegment); dactylus forming a small claw with the nail; merus longer than carpus and ischium. 3rd to 7 th thoracic exopods 13-segmented, basal plate with outer distal corner pointed (Fig. 2C-G).

Eighth thoracopod of the male with a robust barrel-shaped penis; exopod 12-segmented, basal plate without outer distal corner pointed; endopod rather unusually for the tribu Erythropini, shorter than the remaining thoracopods, tubular and without evidence of segmentation (Fig. 3A, B).

On the sternum of each of the second to the eighth thoracic somites of the male there is a prominent, median, forwardly directed, scythe-like process (Fig. 3B). Female with 3 pairs of oostegites, anteriormost pair smaller than others but functional.
Pleopods of male developed, biramous; endopods with side lobe developed (Fig. 3E-I). 1st pleopod with exopod 9-segmented, endopod unsegmented. 2nd and 3rd pleopods with exopod 11-segmented and endopod 6-segmented. 4th pleopod with endopod 12-segmented, two pair of plumose spines on segments 6 and 7; exopod 9-segmented. 5th pleopod with endopod 6-segmented and exopod 9-segmented. Pleopods of the female uniramous, unjointed, increasing in length towards posterior pairs (Fig. 4 F-J).

Endopod of uropod slender, extending beyond apex of telson for $1 / 5$ of its length, armed on inner margin near statocyst with 1 slender spine (Fig. 3D); exopod longer than endopod extending beyond apex of telson for 1/3 of its length (Fig. 3C).

Telson truncate, slightly longer than the last abdominal somite, three times as long as broad at base; lateral margins almost parallel, provided with 23-25 denticles along whole length, distalmost denticle located at terminal end and extending posteriorly beyond distal margin of telson, these denticles without articulation at base; distal margin straight, armed with 4 pairs of long segmented spines and 1 
short unsegmented median spine, plumose setae absent (Figs. 3C, 4E).

Colour in live specimens: whitish tegument with reddish pigment distributed on the anterior ventral zone of the body, mandibles, maxillules, maxillae and thoracic appendages.

Allometric data. An allometric relationship between the carapace length CL (in $\mathrm{mm}$ ) and the total length TL (in $\mathrm{mm}$ ) was calculated from measurements taken in some well-preserved individuals (Fig. 5). Carapace length CL shows an isometric growth in relation to TL (tobs $=0,133 ; 50$ g.l.; $\mathrm{P}<0.001)$.

Etymology. This specific name, antarctica, refers to the locality in which the specimens were collected.

Remarks. The genus Marumomysis resembles the genus Mysimenzies Bacescu, 1971 in many aspects, especially in the reduced eyes, the ventral carina on the first antennular peduncle article, the large antennal scale, the first thoracic endopod with a developed endite on the basis, and the telson with lateral spines without articulation at the base (Murano, 1999). The generic differences, however, are recognised by two main characters: in Mysimenzies the antennular peduncle is provided with a sensory organ in the first article, while such an organ is lacking in Marumomysis; the first thoracic thoracopod is provided with a flagelliform exopod in Marumomysis, whereas in Mysimenzies it possesses no exopod. Murano and Mauchline (1999) recorded ?Mysimenzies sp. from a depth of $3463 \mathrm{~m}$ in the northeast Atlantic. The new species is clearly different from it in the shape and armature of the telson.

The new species resembles Marumomysis hakuhoae Murano, 1999 in the eye with acute horn projecting anteriodorsally, the shape of the rostral plate, and the lateral denticles without articulation of the telson. The main distinguishing morphological characteristic of the new species is recognised in the armature of the telson. Marumomysis antarctica differs from M. hakuhoae in the armature of the lateral margin of telson, provided with more than 20 denticles in $M$. antarctica and 11 denticles in $M$. hakuhoae, and in the number of segmented spines of the distal margin (4 pairs in $M$. antarctica and 3 pairs in $M$. hakuhoae). The new species can be also distinguished from its congener M. hakuhoae by the shape of the labrum (trilobate versus with long slen-

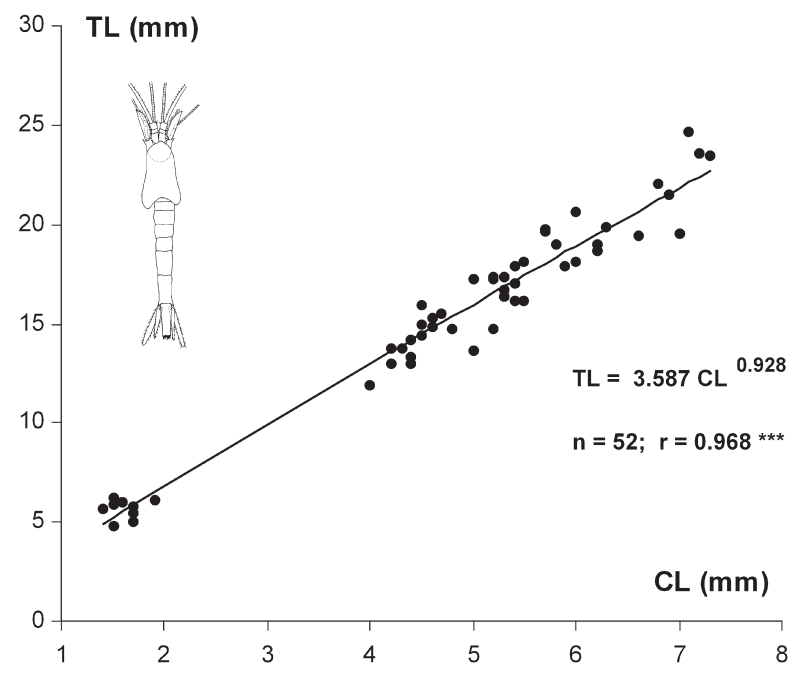

FIG. 5. - Allometric relationship between the total length TL (mm) and the carapace length $\mathrm{CL}(\mathrm{mm})$ of the mysid Marumomysis antarctica n. sp., from Bellingshausen sea (number of individuals examined $=52$ ).

der anterior spine in M. hakuhoae), and the endopod of the uropod (armed with a smooth spine on inner margin near statocyst, furnished with fine setae in M. hakuhoae).

Distribution and demographic analysis. Most of the Marumomysis antarctica individuals sampled by the sled showed a clear vertical distribution gradient with a decrease in abundance between the 10-50 (A) and 55-95 (B) and 100-140 (C) cm water layers, thus confirming a clear preference for a suprabenthic habitat (Table 2). As previously mentioned by San Vicente et al. (1997), these results therefore confirm the interest of suprabenthic sampling methodology for a better knowledge of Antarctic biodiversity.

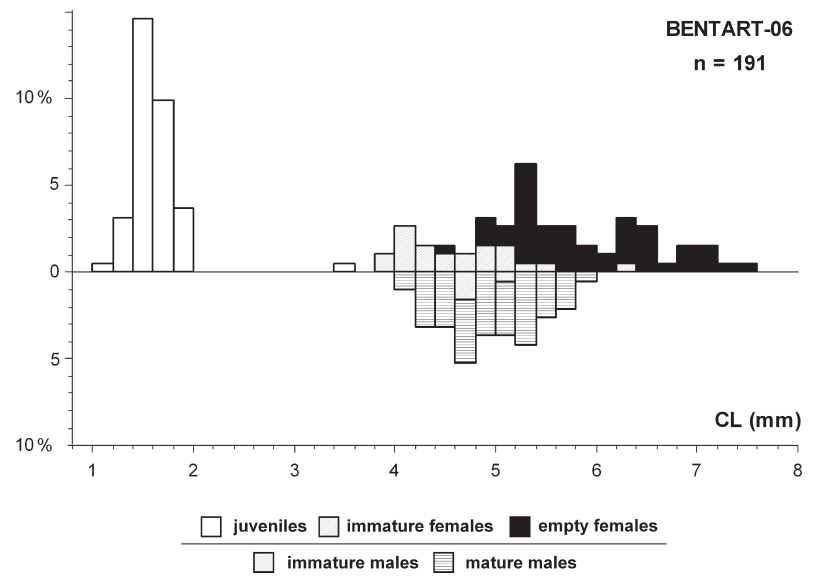

FIG. 6. - Length-frequency histogram of the mysid Marumomysis antarctica n. sp., constructed from the whole material sampled at different stations during BENTART-06 cruise (n: number of individuals examined). 
TABLE 2. - Demographic structure of the mysid Marumomysis antarctica n. sp. sampled at the BENTART-06 stations (N: number of sampled individuals; PNAT: plankton net installed in mouth of 2-m Agassiz trawl).

\begin{tabular}{|c|c|c|c|c|c|c|c|}
\hline Station & Near-bottom water layer & Juveniles & Immature males & Mature males & Immature females & Empty females & $\mathrm{N}$ \\
\hline \multicolumn{8}{|c|}{ Suprabenthic sled } \\
\hline $27 \mathrm{~T}$ & $A(10-50 \mathrm{~cm})$ & 60 & 3 & 47 & 11 & 32 & 153 \\
\hline $27 \mathrm{~T}$ & $\mathrm{C}(100-140 \mathrm{~cm})$ & & & & 1 & & 1 \\
\hline $30 \mathrm{~T}$ & $\mathrm{~A}(10-50 \mathrm{~cm})$ & 1 & & & 2 & 2 & 5 \\
\hline $30 \mathrm{~T}$ & $\mathrm{~B}(55-95 \mathrm{~cm})$ & & & & 1 & 2 & 3 \\
\hline $30 \mathrm{~T}$ & $\mathrm{C}(100-140 \mathrm{~cm})$ & & & & & 1 & 1 \\
\hline $31 \mathrm{~T}$ & $\mathrm{~A}(10-50 \mathrm{~cm})$ & & & 1 & 1 & 4 & 6 \\
\hline $31 \mathrm{~T}$ & B $(55-95 \mathrm{~cm})$ & & & & 1 & & 1 \\
\hline $38 \mathrm{~T}$ & $\mathrm{~A}(10-50 \mathrm{~cm})$ & & 1 & 2 & 4 & 5 & 12 \\
\hline $38 \mathrm{~T}$ & $\mathrm{~B}(55-95 \mathrm{~cm})$ & & & & 1 & 1 & 2 \\
\hline \multicolumn{8}{|c|}{ Total near-bottom water layer } \\
\hline & $\mathrm{A}(10-50 \mathrm{~cm})$ & 61 & 4 & 50 & 18 & 43 & 176 \\
\hline & $\mathrm{B}(55-95 \mathrm{~cm})$ & 0 & 0 & 0 & 3 & 3 & 6 \\
\hline & $\mathrm{C}(100-140 \mathrm{~cm})$ & 0 & 0 & 0 & 1 & 1 & 2 \\
\hline \multicolumn{8}{|l|}{ PNAT } \\
\hline $27 \mathrm{MPK}$ & & 1 & & & & 2 & 3 \\
\hline $30 \mathrm{MPK}$ & & & & & & 1 & 1 \\
\hline $32 \mathrm{MPK}$ & & & & & 1 & & 1 \\
\hline $38 \mathrm{MPK}$ & & & & 2 & & & 2 \\
\hline \multicolumn{2}{|c|}{ TOTAL BENTART-06 } & 62 & 4 & 52 & 23 & 50 & 191 \\
\hline
\end{tabular}

Figure 6 and Table 2 describe the demographic characteristics of the whole population sampled at the 7 BENTART-06 stations at which this species was collected. Individual CL ranged from 1.2 to 7.5 $\mathrm{mm}$ and the histogram clearly showed a polymodal size-frequency distribution (at least 5 modal classes). In the material examined, adults represented $53.4 \%$ of the total stock and brooding females were absent in all samples. Their size-frequency distribution was polymodal with successive modal lengths (CL) at 5.4, 6.5 and 7.1 mm (empty females) and 4.4 and $5.3 \mathrm{~mm}$ (mature males). Juvenile and immature individuals made up $46.6 \%$ of the total stock. Juveniles showed unimodal size-frequency distribution and their CL ranged from 1.2 to $3.6 \mathrm{~mm}$ with a mean value of $1.7 \pm 0.1 \mathrm{~mm}(\overline{\mathrm{x}} \pm$ I.C. $95 \% ; \mathrm{n}=62)$.

According to the demographic pattern herein described, the Marumomysis antarctica population was mainly characterised by the lack of brooding females, suggesting a single winter breeding season, and by the presence of a new generation of juveniles, probably born a few months before the summer in the benthos of the Bellingshausen Sea.

\section{ACKNOWLEDGEMENTS}

The BENTART-06 cruise was carried out within the CGL2004-01856 project (Plan Nacional del
Ministerio de Ciencia y Tecnología). Thanks are due to the crew and officers of RV "Hesperides", Ana Ramos, Fran Ramil, Jordi Corbera, Alfonso Ramos and Jean Claude Sorbe for their helpful assistance during samplings. To all I express my gratitude.

\section{REFERENCES}

Bacescu, M. - 1971. Mysimenzies haddalis g. n., sp. n., a benthic mysid of the Peru Trench, found during Cruise XI/1965 of R/V Anton Bruun (U.S.A.). Rev. Roum. Biol. Zool., 16: 3-8.

Brandt A., U. Mühlenhardt.Siegel and V. Siegel. - 1998. An account of the Mysidacea (Crustacea, Malacostraca) of the Southern Ocean. Ant. Sci. 10(1): 3-11.

Mauchline, J. - 1980. The biology of Mysids and Euphausiids. Advances in Marine Biology, 18. Academic Press, London : $681 \mathrm{pp}$.

Murano, M. - 1999. Marumomysis hakuhoae new genus, new species, from the Sulu Sea (Crustacea: Mysidacea: Mysidae: Erytropini). Plankton Biol. Ecol., 46(2): 148-152.

Murano, M. and J. Mauchline. - 1999. Deep-sea mysids from the North Atlantic Ocean with description of four new species. Crustaceana, 72: 272-295.

San Vicente, C., A. Ramos, A. Jimeno and J.C. Sorbe. - 1997. Suprabenthic assemblages from South Shetland Islands and Bransfield Strait (Antarctica): preliminary observations on faunistical composition, bathymetric and near-bottom distribution. Polar Biol., 18: 415-422.

San Vicente, C., A. Ramos and J.C. Sorbe. - 2006. Suprabenthic euphausiids and mysids from the South Shetland Islands and the Bransfield Strait, Southern ocean (BENTART-95 cruise). Polar Biol., 29: 211-222.

Scient. ed.: J.E. Cartes.

Received February 9, 2007. Accepted July 18, 2007.

Published online October 5, 2007. 